\title{
MOBILE-BASED LITEROOM APPLICATION TO INCREASE SCHOOL LITERATION
}

\author{
Ariyani Dwi Andhini \\ Universitas Muhammadiyah Surakarta, Jawa Tengah, Indonesia \\ Email: ariyanidwiandhinipbi@gmail.com \\ Jeni Nur Cahyati \\ Universitas Muhammadiyah Surakarta, Jawa Tengah, Indonesia \\ Email: jenicahya548@gmail.com \\ Miftakhul Huda \\ Universitas Muhammadiyah Surakarta, Jawa Tengah, Indonesia \\ Email: miftakhul.huda@ums.ac.id
}

DOI: 10.35445/alishlah.v12i1.164

Accepted: December $6^{\text {th }}, 2019$. Approved: June $22^{\text {nd }}, 2020$.

Published: June $30^{\text {th }}, 2020$

\begin{abstract}
The purposes of this study are 1) to provide an update in the field of education related to the school literacy movement, 2) to fostering students' interest in reading in an effort to develop literacy skills. The design of this application is to face the future of the digital era, reduce the use of paper in Indonesia (paper less), and facilitate students in accessing reading material. This research has a scope of design application approach or a new system using the SDLC stage Waterfall model. The results of this study is the design of the Literoom application (Literacy Room), which is a reading room provider application intended for school students for elementary, junior high, and high school equivalent. This application has four main features, namely the reading room, diery room, show of works, and windows of the world. These four features are intended to facilitate students in accessing reading material, increase the ability to titrate, and increase knowledge.
\end{abstract}

Keywords: Application, Literacy, Reading, and Books 
Al-Ishlah: Jurnal Pendidikan - ISSN: 2087-949o (p); 2597-940X (e)

Vol. 12, No. 1 (2020)

\title{
APLIKASI LITEROOM (RUANG LITERASI) BERBASIS MOBILE UNTUK MENINGKATKAN GERAKAN LITERASI SEKOLAH
}

\begin{abstract}
Abstrak
Tujuan dari penelitian ini adalah 1) memberikan pembaharuan dalam bidang pendidikan yang berkaitan dengan gerakan literasi sekolah,dan 2)menumbuhkan minat baca siswa dalam upaya mengembangkan kemampuan berliterasi. Perancangan aplikasi ini digunakan untuk menyongsong era digital masa depan, mengurangi penggunaan kertas di Indonesia (paper less), dan memudahkan siswa dalam mengakses bacaan. Penelitian ini mempunyai cakupan pendekatan rancang bangun aplikasi atau sistem baru dengan menggunakan model Waterfall tahapan SDLC. Hasil dari penelitian ini yakni berupa rancangan aplikasi Literoom (Ruang Literasi), yaitu sebuah aplikasi penyedia ruang baca yang diperuntukkan untuk anak sekolah mulai dari jenjang SD, SMP, dan SMA sederajat. Aplikasi ini memiliki empat fitur utama, yaitu ruang baca, diery room, unjuk karya, dan jendela dunia. Keempat fitur ini diperuntukkan untuk memudahkan siswa dalam mengakses bahan bacaan, menambah kemampaun berliterasi, dan menambah ilmu pengetahuan.
\end{abstract}

Kata Kunci: Aplikasi, Literasi, Membaca, dan Buku

\section{PENDAHULUAN}

Indonesia dipandang sebagai negara yang memliki tingkat minat baca yang rendah. Menurut survei CCSU Indonesia berada diurutan 60 dari 61 negara yang disurvei. Ditingkat internasional, Indonesia memiliki indeks membaca 0,001 (Kasiyun, 2015). Rendahnya minat baca ini didasari beberapa faktor. Pertama, akses buku yang sulit. Minimnya ketersediaan buku pada lembaga pendidikan maupun perpustakaan daerah menjadi salah satu penyebab minat baca masyarakat Indonesia. Kedua, buku cetakan Indonesia kurang bagus. Oleh karena itu yang menjadi faktor rendahnya minat baca di Indonesia bukan dari orangnya, melainkan kondisi bukunya yang kebanyakan tidak menarik. Selain itu, jumlah buku yang minim juga menjadi indikator dalam rendahnya minat baca. Hal ini dibuktikan dengan jumlah penerbitan buku yang hanya mencapai 5000-10.000 pertahun (Wedhaswary, 2012)

Kegiatan literasi 15 menit di sekolah sebelum pembelajaran dipandang kurang efektif. Hal ini dikarenakan minimnya kesediaan buku bacaan berkualitas dan jumlahnya yang tidak memadai. Kendala yang cukup menonjol yang melatar belakangi minat baca ialah harga buku di Indonesia termasuk mahal jika dibandingkan dengan negara lain misalnya Jepang. Ketua Umum Ikatan Penerbit 
Al-Ishlah: Jurnal Pendidikan - ISSN: 2087-949o (p); 2597-940X (e)

Vol. 12, No. 1 (2020)

Indonesia (IKAPI) mengakui tingginya harga buku di Indonesia, diungkapkan oleh beliau bahwa penerbitan buku dikenai pajak kertas yang tinggi (Untarni dan Yanuar, 2016). Untuk menyikapi hal ini, sebaiknya pemerintah mulai merevolusi to paperless, artinya penyediaan bacaan mulai beralih ke media digital. Banyak kemudahan jika pendidikan di Indonesia mampu berevolusi ke e-paper, Kemdikbud dan perpustakaan bisa langsung membagikan buku melalui situs resmi mereka. Selain itu, e-paper juga mampu mengurangi penggunaan kertas yang berlebihan, sehingga hutan di Indonesia tetap terjaga kelestariannya.

Dunia sedang memasuki revolusi digital. Dalam hal ini semua aktivitas akan beralih ke dunia maya atau dengan kata lain berbasis digital. Industri 4.0 memperkenalkan konsep teknologi inovatif dengan cara baru (Mourtzis, dkk., 2018). Hampir saat ini semua orang sulit terlepas dari produk digital, khususnya gadget. Gadget dikategorikan sebagai alat canggih yang dirancang dengan berbagai aplikasi yang dapat menampilkan berbagai media informasi, jejaring sosial, hobi, maupun hiburan (Manumpil, 2015). Gadget juga dipandang sebagai barang yang praktis dan mudah dibawa. Gadget ini dapat digunakan dalam dunia pendidikan, khususnya untuk menunjang kegiatan literasi sekolah. Oleh karena itu diperlukan sebuah aplikasi yang mampu menyediakan bacaan untuk anak sekolah dengan tampilan menarik. Media literasi, literasi informasi, dan literasi digital adalah tiga konsep yang paling berlaku yang berfokus pada pendekatan kritis terhadap pesan media (Koltay, 2011).

Pendidikan pada era industri 4.0 ditujukan untuk kebutuhan masyarakat di era yang inovatif. Manajemen pembelajaran harus membantu mengembangkan kemampuan peserta didik dalam menerapkan teknologi baru yang dapat membantu peserta didik mengembangkan potensi sesuai dengan perubahan dalam masyarakat (Puncreobutr, 2016). Dengan demikian diperlukan sistem belajar baru, yang mana memungkinkan peserta didik untuk tumbuh dengan pengetahuan dan keterampilan untuk seluruh kehidupan, bukan hanya tahu bagaimana membaca dan menulis. Hal ini dikarenakan belajar adalah tindakan untuk mendapatkan tingkat pengetahuan yang lebih tinggi (Agustin, 2013). Dengan menggunakan sebuah aplikasi literasi berbasis mobile dipandang cukup signifikan dalam upaya menunjang gerakan literasi di sekolah.

Dari uraian mengenai kondisi literasi di Indonesia yang kaitannya dengan era digital yang semakin berkembang maka peneliti berinisiatif untuk menciptakan sebuah aplikasi yang mampu diakses dengan mudah dari gadget dengan tampilan yang menarik. Aplikasi ini menyediakan ruang untuk membaca dengan ketersediaan buku yang memadai dan beragam untuk anak sekolah. Aplikasi ini diharapkan nantinya mampu menjadi akses dalam peningkatan literasi di Indonesia. Aplikasi ini sangat penting untuk membantu peningkatan gerakan literasi di sekolah seperti yang diupayakan oleh pemerintah. 
Al-Ishlah: Jurnal Pendidikan - ISSN: 2087-949o (p); 2597-940X (e)

Vol. 12, No. 1 (2020)

\section{METODE PENELITIAN}

Penelitian ini mempunyai cakupan pendekatan rancang bangun aplikasi atau sistem baru. Karena hasil luaran dari penelitian ini berupa sebuah aplikasi, maka dalam proses pengembangan media digunakan Waterfall model. Pemerolehan data dari penelitian ini melalui kuesioner oleh responden yang berupa minat baca. Dalam hal ini gerakan literasi sekolah yang berkaitan dengan buku bacaan menjadi sumber data dalam penciptaan sebuah aplikasi ruang baca. Untuk menguji sejauh mana keakuratan dan ketepatan aplikasi, maka perlu dilakukan uji coba kuesioner sebagai alat ukur. Untuk pengujian data digunakan uji validitas dan realibilitas dari daftar pertanyaan yang menjadi subjek. Uji validitas digunakan untuk mengetahui kelayakan butir pertanyaan berkaitan dengan rancangan aplikasi. Sedangkan, untuk kuesioner dikatakan reliabel atau andal, apabila jawaban responden terhadap pertanyaan adalah konsisten (stabil) dalam periode waktu tertentu. Hasil penelitian ini akan menjadi valid apabila instrumen dalam pengumpulan datanya valid dan reliabel (Kasiram, 2008).

Dalam proses pengembangan media, penelitian ini menggunakan Waterfall model. Model waterfall merupakan model tradisional yang bersifat sistematis dan berurutan dalam merancang sebuah software (Pressman, 2015: 42). Alasan menggunakan model ini, karena proses pelaksanaannya bertahap sehingga tidak berfokus pada tahapan tertentu. Adapun analisis data yang dipakai dalam penelitian ini adalah statistik deskriptif. Deskriptif diartikan sebagai cara untuk mendeskripsikan keseluruhan variabel yang dipilih dengan cara mengalkulasi data sesuai kebutuhan peneliti (Nugroho, 2011). Dengan menggunakan analisis ini, diharapkan mampu menampilkan gambaran atau deskripsi empiris dari data yang dikumpulkan dalam penelitian.

SDLC model waterfall digunakan sebagai metode pengembangan sistem dari aplikasi Literoom ini. Adapun tahapannya, seperti yang dilakukan oleh (Sobri dan Leon, 2013).

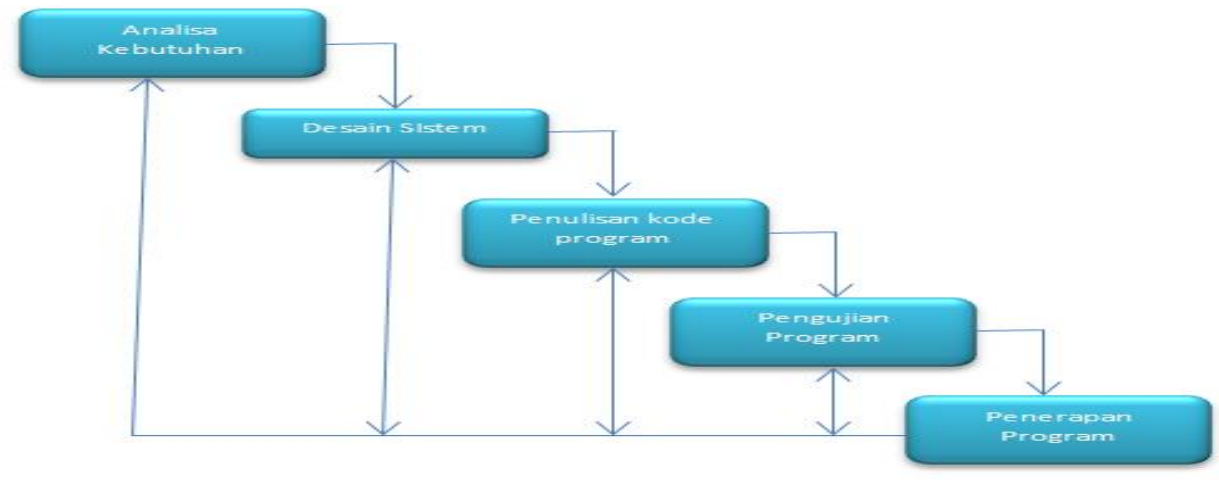

Gambar 1 Aliran Metodologi Penelitian 
Al-Ishlah: Jurnal Pendidikan - ISSN: 2087-949o (p); 2597-940X (e)

Vol. 12, No. 1 (2020)

\section{HASIL DAN PEMBAHASAN}

Hasil dari penelitian ini berupa aplikasi penyedia ruang baca sebagai wujud pengembangan gerakan literasi sekolah. Aplikasi ini menggunakan teknologi mobile sebagai perangkat bergerak dalam pembelajaran. Bagi peserta didik Mobile Learning dipandang sebagai nilai tambahan yang dapat digunakan dalam pembelajaran E-Learning (Rizal, 2013). Aplikasi ini dibagi menjadi empat sub menu utama yang masing-masing memiliki sub menu view. Dalam sub menu ini menyediakan berbagai fitur layanan. Fitur yaitu komponen pelengkap dan menjadi ciri khas dari suatu perangkat lunak (software) yang dapat menjalankan suatu proses tertentu (Sopandi, 2016). Peneliti berupaya untuk memberikan penjelasan mengenai jumlah hasil yang didapat dari aplikasi ruang baca. Adapun penjelasan akan dimulai dari penguraian menu utama, sub menu file, sub menu view, dan sub menu about.

\section{Menu Utama}

Dalam menu utama ini memiliki beberapa sub menu, antara lain sub menu file, sub menu view, sub menu materi, dan sub menu about. Menu utama berfungsi sebagai inti dari aplikasi Literoom ruang baca, karena semua fitur terdapat pada menu utama. Berikut tampilan menu utama dari aplikasi Literoom.

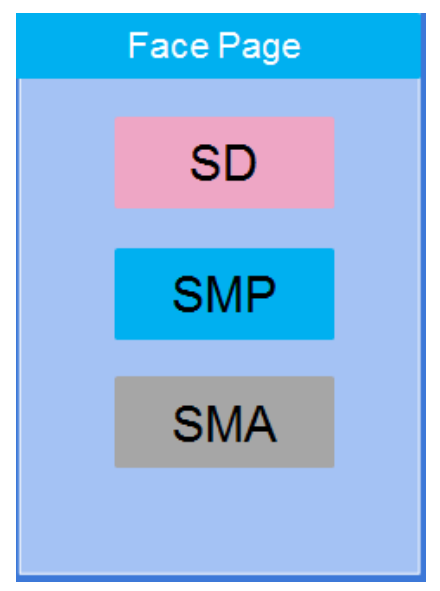

Gambar 2 Menu Utama

Dalam menu utama ini terdapat pilihan jenjang pendidikan yang disesuaikan dengan jenjang siswa sebagai user, mulai dari SD, SMP, dan SMA (sederajat). Jenjang pendidikan ini yang akan membedakan isi atau konten bacaan dan materi dari aplikasi ruang baca. Hal ini dikarenakan konten yang disediakan dalam aplikasi disesuaikan dengan usia peserta didik.

Setelah peserta didik memilih jenjang pendidikan yang sesuai, selanjutnya harus login sebagai validasi user. User dapat login dengan NISN (Nomor Induk 
Al-Ishlah: Jurnal Pendidikan - ISSN: 2087-949o (p); 2597-940X (e)

Vol. 12, No. 1 (2020)

Siswa Nasional) dan kata sandi (password) yang sudah diberikan oleh Dinas Pendidikan Nasional. Berikut tampilan menu login dari aplikasi Literoom.

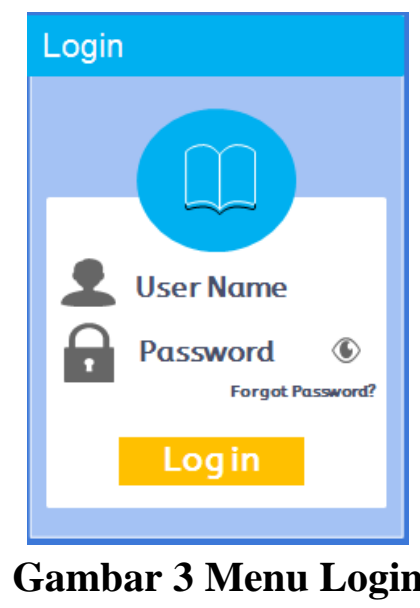

\section{Sub Menu File}

Sub menu file menyediakan informasi mengenai fitur yang ada dalam aplikasi Literoom. Fitur yang ada dalam submenu ini antara lain: ruang baca, diery room, unjuk karya, dan jendela dunia. Masing-masing fitur memiliki muatan materi yang bisa digunakan siswa untuk menambah wawasan dan meningkatkan kemampuan literasi siswa. Hal ini sejalan dengan manfaat M-Learning, yaitu Mobile Learning memilikikegunaan untuk menyediakan bahan ajar yang dapat diakses secara efisiendengan penyajian materi yang menarik (Listyorini, 2013).Berikut tampilan sub menu file.

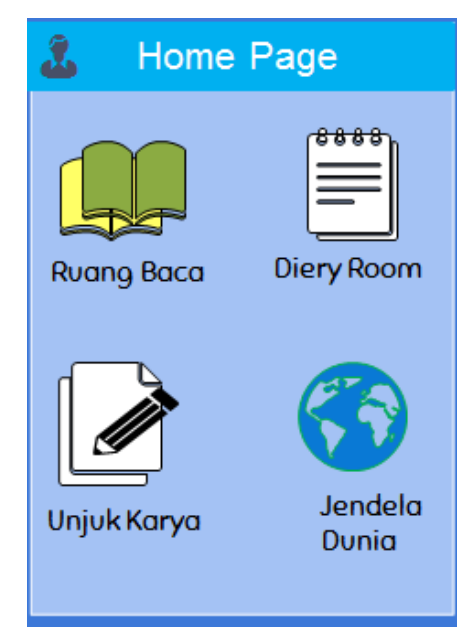

Gambar 4 Sub Menu File

Dalam sub Ruang Baca menyediakan fitur bacaan yang berupa dari buku non fiksi dan buku fiksi. Peningkatan minat baca dapat dilakukan dengan usaha 
Al-Ishlah: Jurnal Pendidikan - ISSN: 2087-949o (p); 2597-940X (e)

Vol. 12, No. 1 (2020)

memelihara, mempertahankan, dan meningkatkan kualitas bacaan (Nafisah, 2014). Untuk meningkatkan minat baca siswa, buku bacaan ini disajikan dalam bentuk buku online (e-book). Ketika sekolah masih menerapkan 15 menit membaca sebelum pembelajaran, siswa bisa membuka ruang baca ini dan memilih buku yang ingin dibaca. Dengan kemampuan membaca yang baik, kemampuan yang lain akan ikut tertunjang, mengingat membaca merupakan gerbang untuk mengaktifkan skemata dalam otak sehingga kemampuan menulis dan berbicara siswa turut berkembang (Huda, 2018). Selanjutnya fitur Diery Room dipakai sebagai ruang untuk menulis ringkasan dari buku yang sudah dibaca. Selanjutnya hasil ringkasan ini bisa dikirim ke guru Bahasa Indonesia untuk mengetahui tingkat kemampuan literasi dari siswa. Fitur Unjuk Karya merupakan ruang yang disediakan untuk menulis dan mengunggah karya tulis dari siswa. Karya tulis ini bisa berupa puisi, pantun, artikel, atau coretan tulisan lainnya yang dapat diunggah dan mendapat feedback dari pengguna lain. Fitur Jendela Dunia merupakan fitur yang menyediakan beragam informasi untuk menambah wawasan siswa.

\section{Sub Menu View}

Sub menu view memiliki empat fitur yang merupakan isi dari sub menu file, yaitu ruang baca, diery room, unjuk karya, dan jendela dunia. Sub menu view ini menyajikan berbagai fitur dalam kaitannya dengan kegiatan literasi. Berikut tampilan dari empat sub menu view.

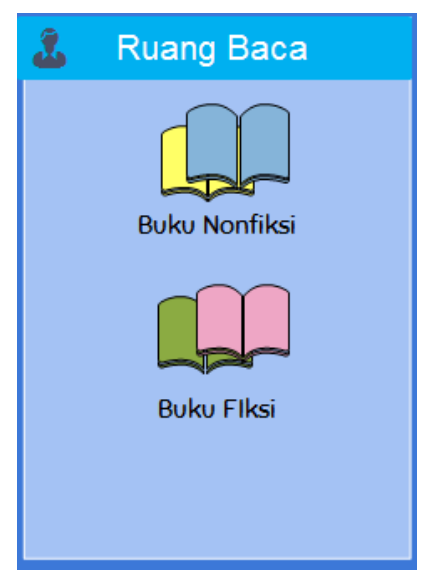

Gambar 5 Sub Menu View Ruang Baca 
Al-Ishlah: Jurnal Pendidikan - ISSN: 2087-949o (p); 2597-940X (e)

Vol. 12, No. 1 (2020)

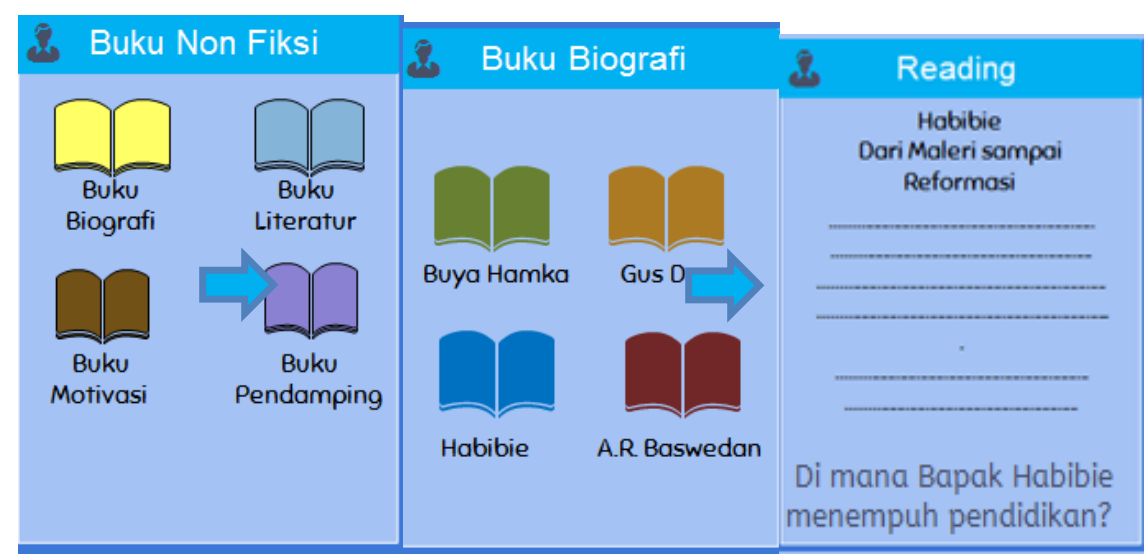

Gambar 6 Tampilan Sub Menu Buku Nonfiksi

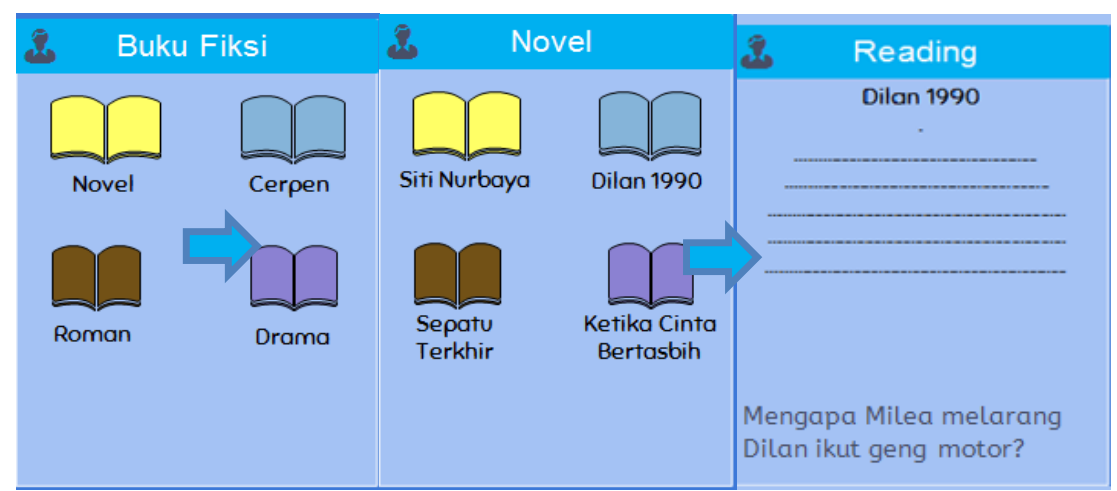

Gambar 7 Tampilan Sub Menu Buku Fiksi

Pada fitur ruang baca ini menyediakan berbagai buku bacaan dalam bentuk e-book. Buku bacaan ini terbagi dalam kategori buku non fiksi dan buku fiksi. Ketika sekolah masih menerapkan 15 menit membaca sebelum pembelajaran, siswa bisa membuka ruang baca ini dan memilih buku yang ingin dibaca. Untuk mengetahui apakah siswa benar-benar membaca atau tidak, pada tampilan halaman tertentu akan diberikan pertanyaan, dan siswa harus menjawab pertanyaan tersebut. Selanjutnya siswa dapat meringkas hasil bacaannya ke fitur Diery Room. Berikut tampilan dari sub menu view Diery Room. 
Al-Ishlah: Jurnal Pendidikan - ISSN: 2087-949o (p); 2597-940X (e)

Vol. 12, No. 1 (2020)

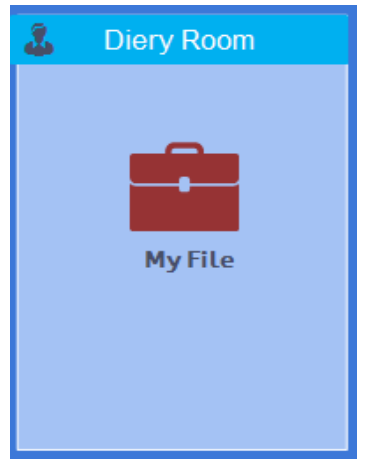

\section{Gambar 8 Sub Menu View Diery Room}

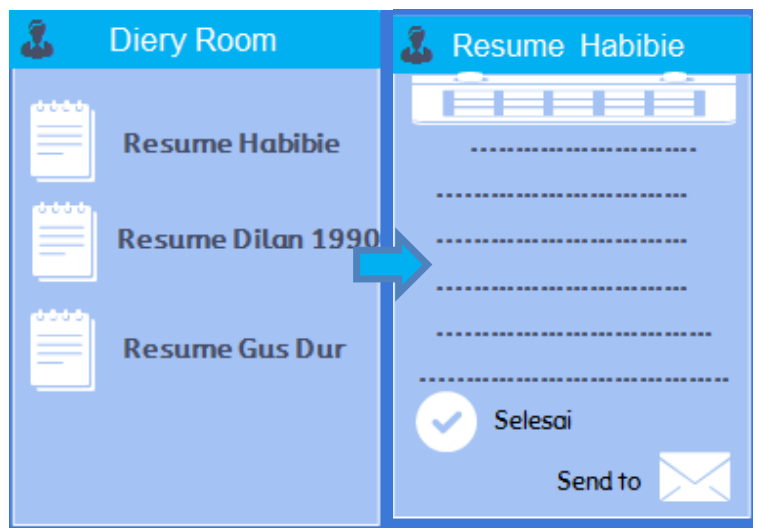

\section{Gambar 9 Tampilan Sub Menu View Diery Room}

Fitur Diery Room ini menyediakan ruang bagi siswa untuk menulis ringkasan dari buku yang telah mereka baca. Ringkasan yang ditulis bisa disimpan kemudian dikirim kepada guru Bahasa Indonesia. Dengan hal ini, guru Bahasa Indonesia dapat mengetahui tingkat kemampuan menulis siswa, guru juga mampu memberi saran untuk tulisan yang siswa tulis. Guru juga mampu memberi motivasi siswa untuk giat menulis. Aplikasi ini menyediakan siswa untuk berkarya tulis dan mengunggah hasil karya dalam fitur yang bernama Unjuk Karya. Berikut tampilan sub menu view unjuk karya . 
Al-Ishlah: Jurnal Pendidikan - ISSN: 2087-949o (p); 2597-940X (e)

Vol. 12, No. 1 (2020)

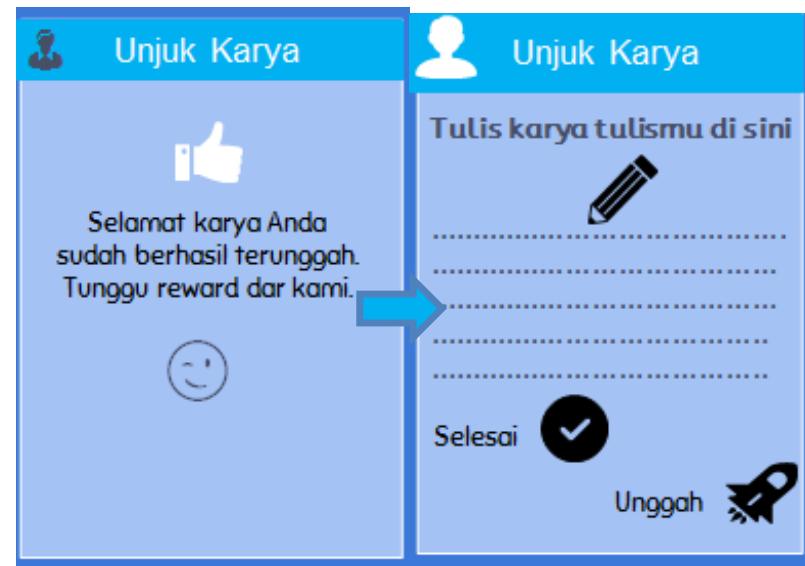

Gambar 10 Sub Menu View Unjuk Karya

Pada sub menu view Unjuk Karya ini siswa mampu bereksplorasi mengembangkan segala ide dan imajinasinya dalam sebuah tulisan. Tulisan ini dapat berupa puisi, pantun, artikel, maupun coretan tulisan lainnya. Hasil tulisan siswa dapat diunggah pada aplikasi ini. Selanjutnya siswa akan mendapat apresisasi berupa like dan comment layaknya sosial media. Selain itu, siswa yang berhasil mengunggah karya tulisnya akan mendapat koin literasi.

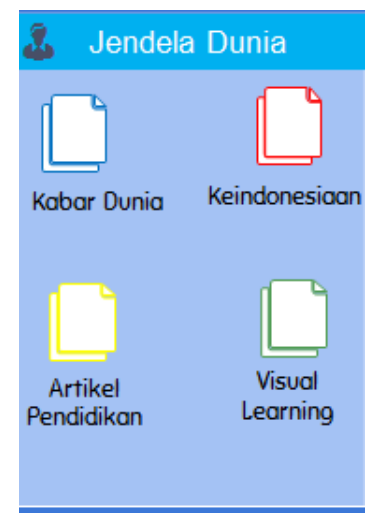

\section{Gambar 11 Sub Menu View Jendela Dunia}

Sub menu view Jendela Dunia menyediakan materi berupa ilmu pengetahuan yang berguna untuk menambah wawasan siswa. Sub menu view ini mempunyai fitur yang terbagi dalam empat kategori yaitu kabar dunia, keindonesiaan, artikel pendidikan, dan visual learning. 
Al-Ishlah: Jurnal Pendidikan - ISSN: 2087-949o (p); 2597-940X (e)

Vol. 12, No. 1 (2020)

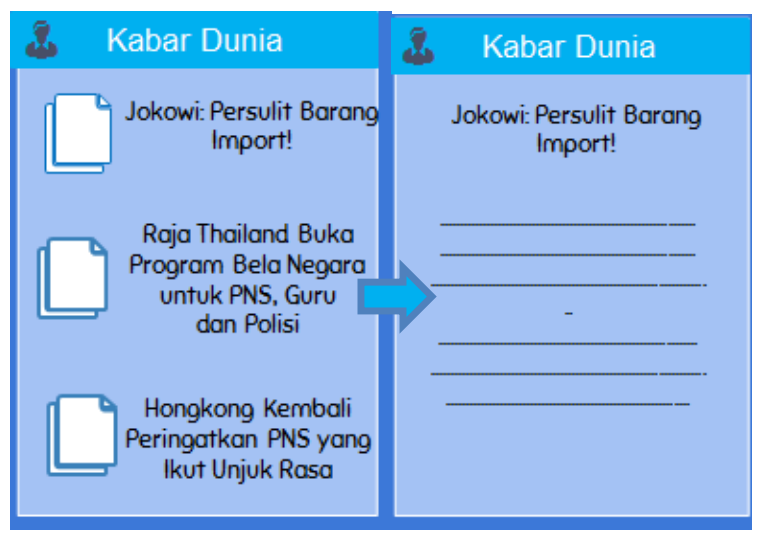

Gambar 12 Tampilan Fitur Kabar Dunia

Fitur kabar dunia memuat informasi atau berita yang sedang menjadi topik utama. Dalam fitur ini siswa mampu mengetahui berbagai berita yang sedang menjadi pembicaraan utama (trending) di dunia, sehingga dapat menambah pengetahuan dan informasi siswa.

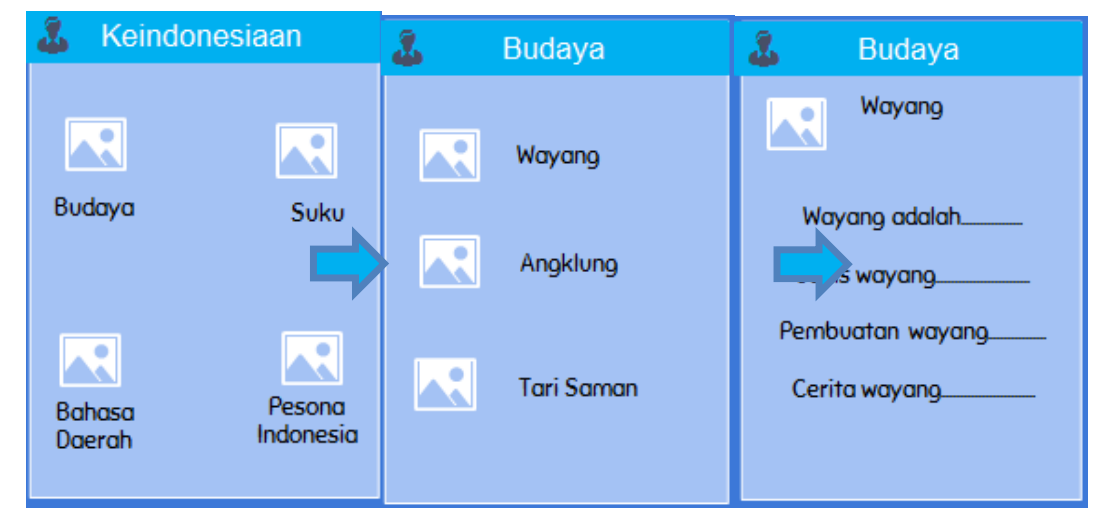

Gambar 13 Tampilan Fitur Keindonesiaan

Fitur keindonesiaan memuat segala hal yang berkaitan dengan negara Indonesia, berupa suku dan budayanya. Dalam fitur ini menyediakan berbagai hal mengenai Indonesia, mulai dari budaya, suku, bahasa daerah, dan pesona Indonesia. Keempat menjadi aspek penting untuk siswa dalam mengembangkan rasa cinta tanah air. 
Al-Ishlah: Jurnal Pendidikan - ISSN: 2087-949o (p); 2597-940X (e)

Vol. 12, No. 1 (2020)

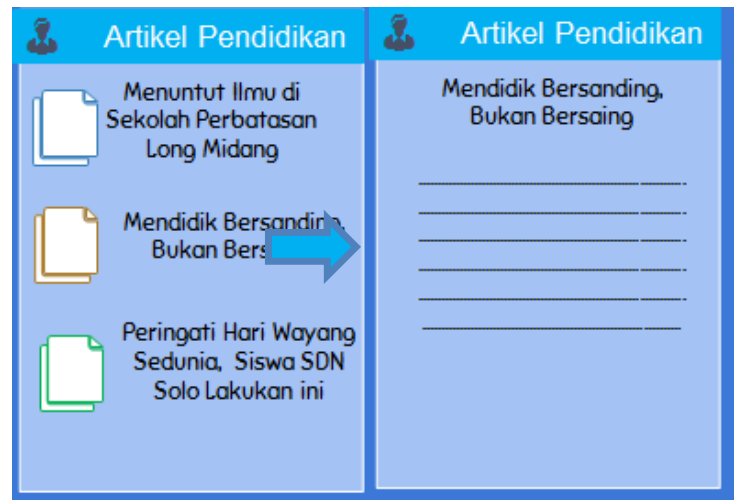

Gambar 14 Tampilan Fitur Artikel Pendidikan

Fitur artikel pendidikan memuat segala informasi yang terkait dengan pendidikan, mulai dari sistem pembelajaran, karya ilmiah, inovasi dalam pendidikan, dll. Dalam fitur ini disajikan informasi berupa berita dalam bentuk artikel yang berkaitan dengan satuan pendidikan.

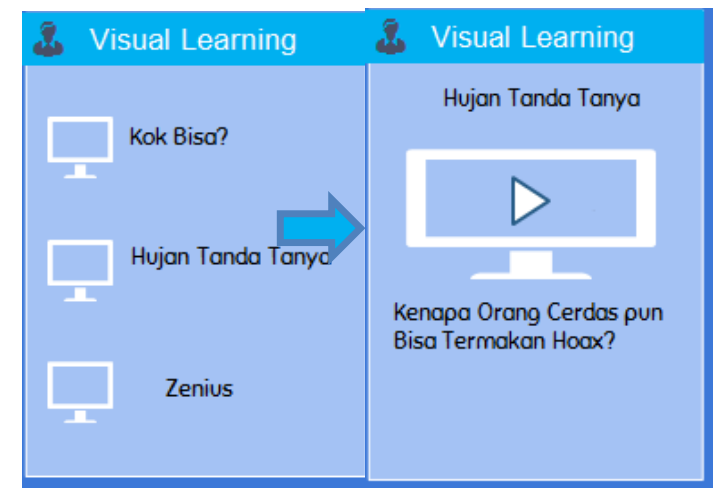

\section{Gambar 15 Tampilan Fitur Visual Learning}

Fitur visual lerning, ini merupakan fitur yang menyediakan kajian materi yang disajikan dalam bentuk video. Video yang disediakan berkaitan dengan dunia pendidikan dan ilmu pengetahuan. Video ini didapat dari channel youtube yang berkonten pendidikan dan ilmu pengetahuan, seperti Kok Bisa?, Hujan Tanda Tanya, dan Zenius. Ketiga channel ini diharapkan mampu menambah pengetahuan dan memudahkan siswa dalam belajar.

\section{Sub Menu About}

Sub menu about memuat informasi dari user (siswa). Informasi tersebut dapat berupa identitas, aktivitas, koin liter, dan pengaturan. Sub menu juga menjadi pusat kendali dari aktivitas siswa pada Literoom. Berikut tampilan sub menu about. 
Al-Ishlah: Jurnal Pendidikan - ISSN: 2087-949o (p); 2597-940X (e)

Vol. 12, No. 1 (2020)

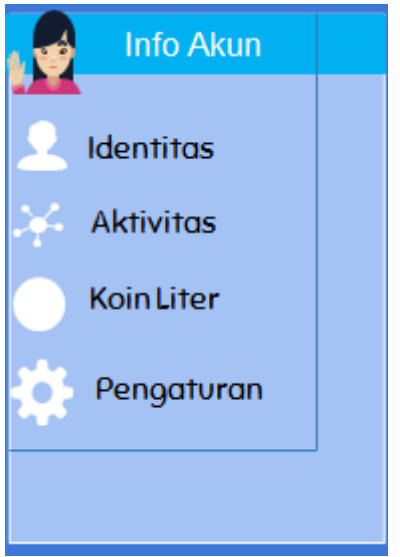

Gambar 16 Sub Menu About

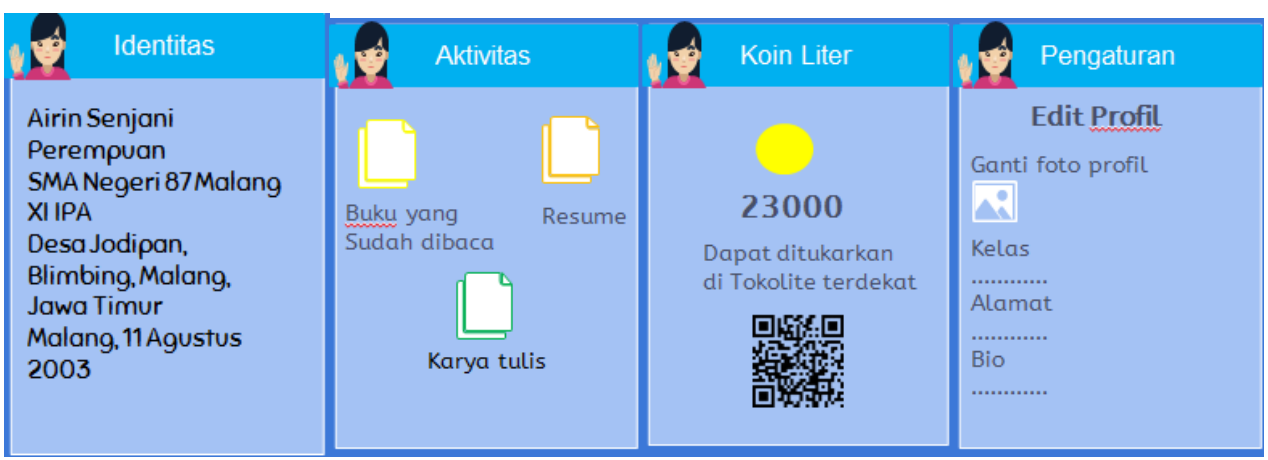

Gambar 17 Tampilan Fitur About Info Akun

Pada fitur identitas memuat informasi tentang data diri siswa, yang mencakup nama siswa, institusi (sekolah), kelas, alamat, tempat tanggal lahir, dan jenis kelamin. Fitur aktivitas berisi informasi mengenai buku apa saja yang sudah dibaca, ringkasan yang sudah dibuat, dan karya tulis yang sudah diunggah oleh siswa. Selanjutnya koin liter berisi koin atau reward yang didapat siswa dari aktivitas berupa unggahan karya tulis. Koin liter ini dapat ditukar dengan alat tulis melalui barcode pada toko yang sudah menyediakan alat tulis berbasis Literoom yang disebut 'Tokolite', seperti Gramedia atau Togamas. Sedangkan, pengaturan memuat fitur untuk mengelola atau mengendalikan aplikasi Literoom. Misalnya mengganti foto profil dan data diri siswa.

Desain perancangan sistem aplikasi Literoom berbasis mobile menggunakan diagram case yang meliputi user case, admin case, dan activity case. Mobile merupakan sebuah alatdengan teknologi canggih yang mampu beroperasi tanpa kabel atau nirkabel (Efendi, 2018).Perancangan basis data digunakan untuk memodelkan sistem perangkat lunak yang akan dibangun berdasarkan sudut pandang struktur data base atau basis datanya (Justicia, 2017). Dalam pengolahan data atau literatur, peranan dari sebuah aplikasi sangat dominan, karena bahan literasi akan dipahami lebih spesifik (Zainul, 2016). Pada 
Al-Ishlah: Jurnal Pendidikan - ISSN: 2087-949o (p); 2597-940X (e)

Vol. 12, No. 1 (2020)

umumnya perangkat dari aplikasi mobile mempunyai karakteristik, di antaranya: 1) Keterbatasan Central Procesing Unit (CPU) dan Graphical Processor Unit (GPU), 2) Ukuran tampilan layar yang minimalis, 3) Keberagaman lingkungan pengoperasian(mobile contecxt), dan 4) Kurang andal dalam koneksi internet (Zhang \& Adipat dalam Efendi, 2018).Sistem operasi saat ini dimanfaatkan dalamkurikulum program studi, khususnya program studi yang mengutamakan teknologi informasi (Listyorini, 2013). Berikut rancangan sistem user case.

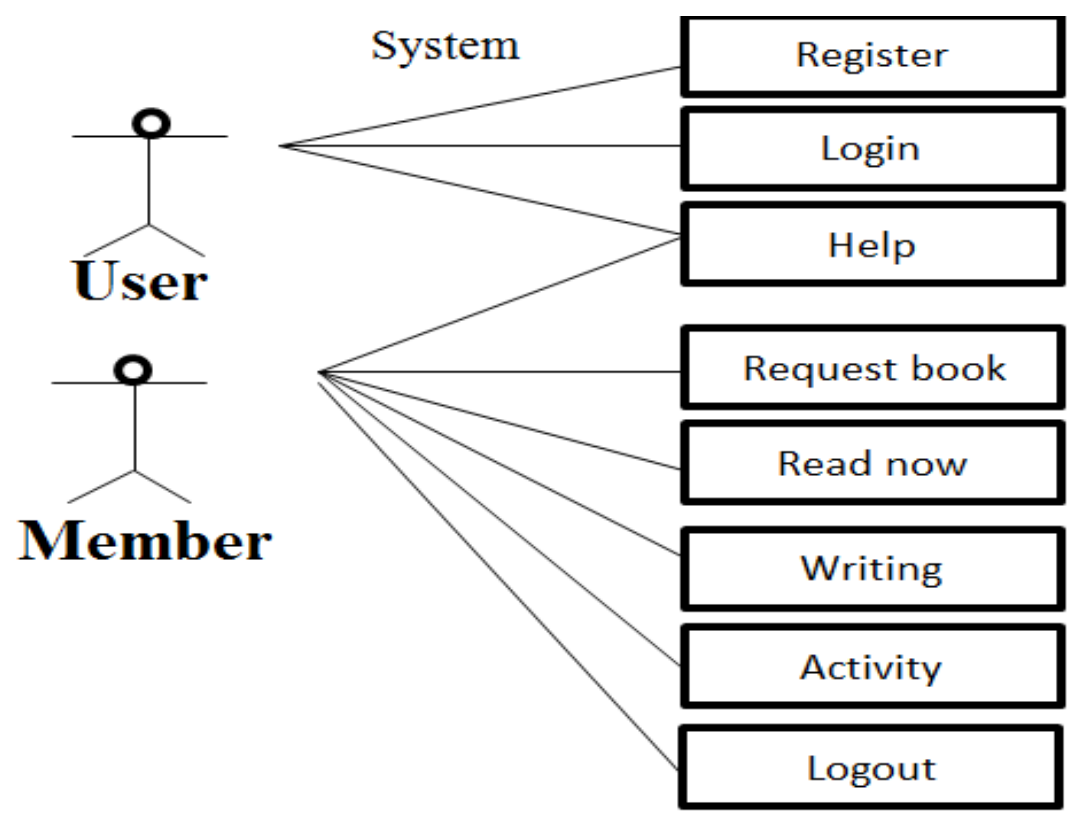

\section{Gambar 18 Sistem User Case}

Pada gambar 18 dijelaskan tentang alur sistem user case mewakili aktivitas dari pengguna aplikasi Literoom. User adalah seseorang yang menggunakan sistem informasi atau pengguna layanan informasi (O'Brien, 2006). Hal yang dapat dilakukan user yakni mulai dari registrasi sebagai proses validasi user yang diberikan akses dari Kemendikbud berupa username NISN dan password, sehingga user dapat login. Apabila user mengalami kesulitan saat login, terdapat tombol help yang berisikan petunjuk bantuan dan tata cara login dengan benar. Selanjutnya user dapat melakukan aktivitas literasi, mulai book request, user dapat memilih buku yang akan dibaca, kemudian menyimpulkan, menulis karya tulis, sampai logout dari aplikasi Literoom.

Pada diagram case terdapat sistem admin case sebaagi sistem pengendali dari aplikasi Literoom. Admin disebut juga sebagai seseorang yang berwenang mengelola website dengan melakukan pembaruan sejumlah isi dari web dan mengendalikan proses dari forum diskusi, serta pemberian respons atau reward 
Al-Ishlah: Jurnal Pendidikan - ISSN: 2087-949o (p); 2597-940X (e)

Vol. 12, No. 1 (2020)

(Napitupulu, 2008). Berikut gambaran rancangan sistem admin case pada aplikasi Literoom.

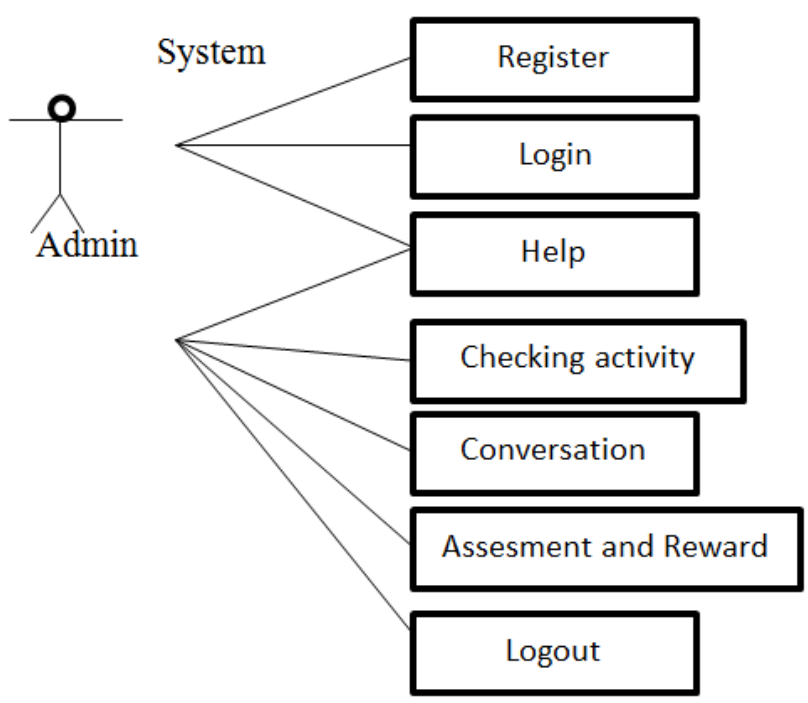

Gambar 19 Sistem Admin Case

Pada gambar 19 dijelaskan tentang alur sistem admin case yang mewakili pengendalian administrator aplikasi Literoom. Admin berperan sebagai pengatur data dari user dalam sebuah aplikasi, misalnya dalam hal penambahan, pengubahan, dan penggunaan data user (Isnanto, 2009). Aplikasi ini dikendalikan oleh seorang admin dalam satu sekolah. Dalam hal ini, admin juga harus registrasi terlebih dahulu sebelum masuk ke aplikasi. Setelah mendapat username dan password dari Kemendikbud untuk login ke aplikasi Literoom. Terdapat tombol 'help' untuk membantu dalam proses login ketika terjadi kesalahan. Admin juga mampu mengawasi aktivitas dari user, memberi penilaian atau apresiasi terhadap karya tulis dari siswa, peemberian reward yang berupa koin liter, serta terdapat fitur logout untuk tombol keluar admin.

Dalam activity diagram digambarkan hubungan alur dari sistem kerja antara user case dan admin case. Keduanya saling berkaitan dengan satu pengendali pusat. Activity diagram dapat diketahui sebagai alur atau sering disebut sophisticated data flow diagram (DFD) yang dimanfaatkandalam analisis structural (Suryasari, 2012). Dalam aplikasi Literoom ini yang menjadi pusat dari aktivitas user case dan admin case adalah Kemendikbud. Berikut tampilan rancangan sistem activity diagram. 
Al-Ishlah: Jurnal Pendidikan - ISSN: 2087-949o (p); 2597-940X (e)

Vol. 12, No. 1 (2020)

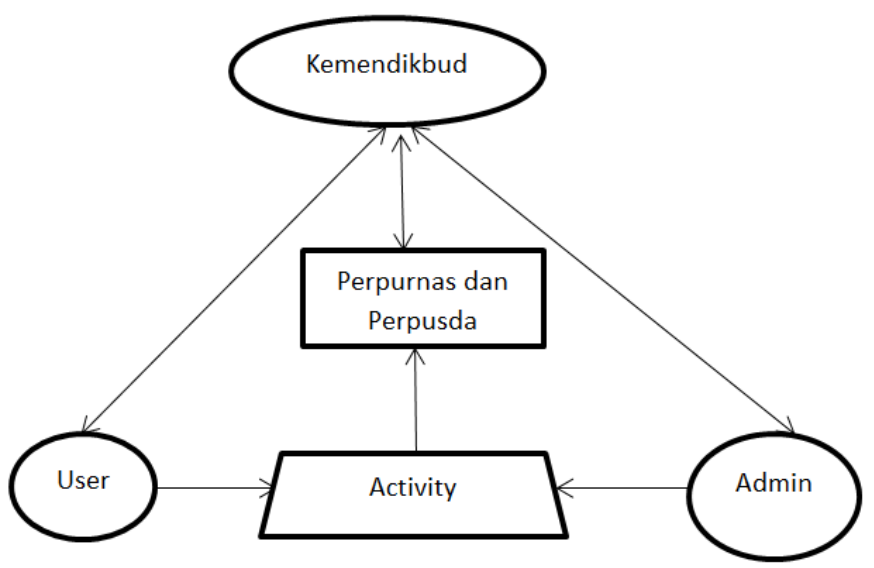

Gambar 20 Sistem Activity Diagram

Pada gambar 20 dijelaskan alur dari sistem kerja antara user case dan admin case. User sebagai pengguna melakukan berbagai aktivitas dalam aplikasi Literoom. Admin bertugas mengawasi dan mengendalikan aktivitas dari user. Dalam penyediaan aktivitas user dan admin, semua atas koordinasi dari Perpustakaan Nasional dan Perpustakaan Daerah sebagai penyedia materi berupa buku bacaan dari aplikasi Literoom ini. Perpustakaan dipandang sebagai institusi yang bertugas dalam pengumpulan, pengelolaan, dan penyebaran informasi, sebab itu perpustakaan dituntut untuk aktif dan inovatif dalam pemberian dan penciptaan layanan berbasis Teknologi Informasi (TI) kepada masyarakat (Syaikhu dan Zakiah, 2010). Dalam hal ini, Literoom menjadi alternatif pengembangan perpustakaan berbasis mobile yang mudah diakses oleh pengguna. Keseluruhan aktivitas dari user, admin, dan perpustakaan dikendalikan atas koordinasi dari Kemendikbud sebagai pengelola pendidikan di Indonesia. Berikut tampilan admin sebagai pengendali aplikasi Literoom.

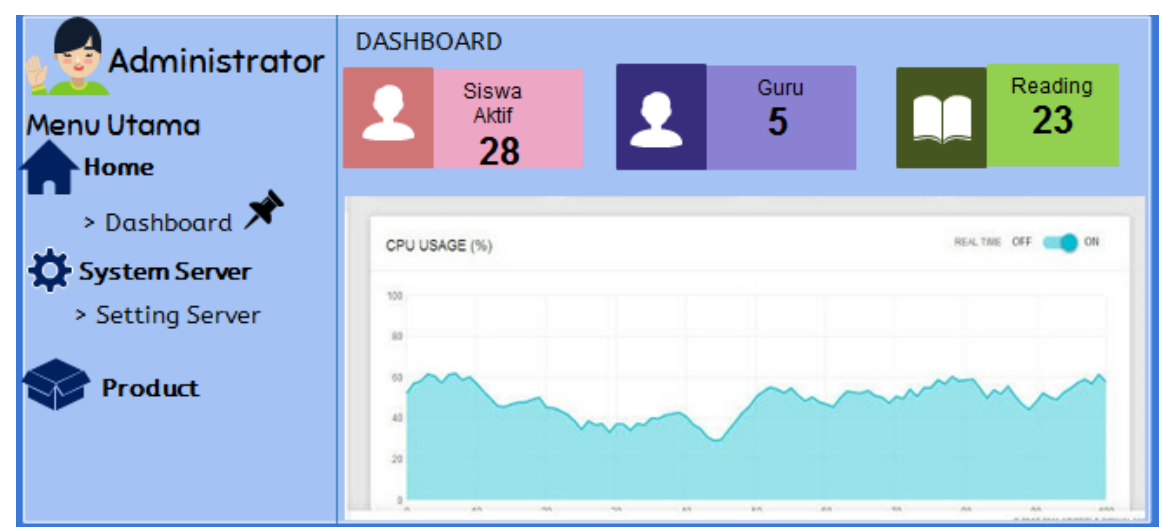

Gambar 21 Tampilan Admin Fitur Dashboard 
Al-Ishlah: Jurnal Pendidikan - ISSN: 2087-949o (p); 2597-940X (e)

Vol. 12, No. 1 (2020)

Pada fitur dashboard menampilkan aktivitas dari user, yakni siswa dan guru. Dalam fitur ini akan diketahui jumlah user yang sedang mengakses aplikasi, serta diketahui jumlah buku yang sedang diakses oleh user.

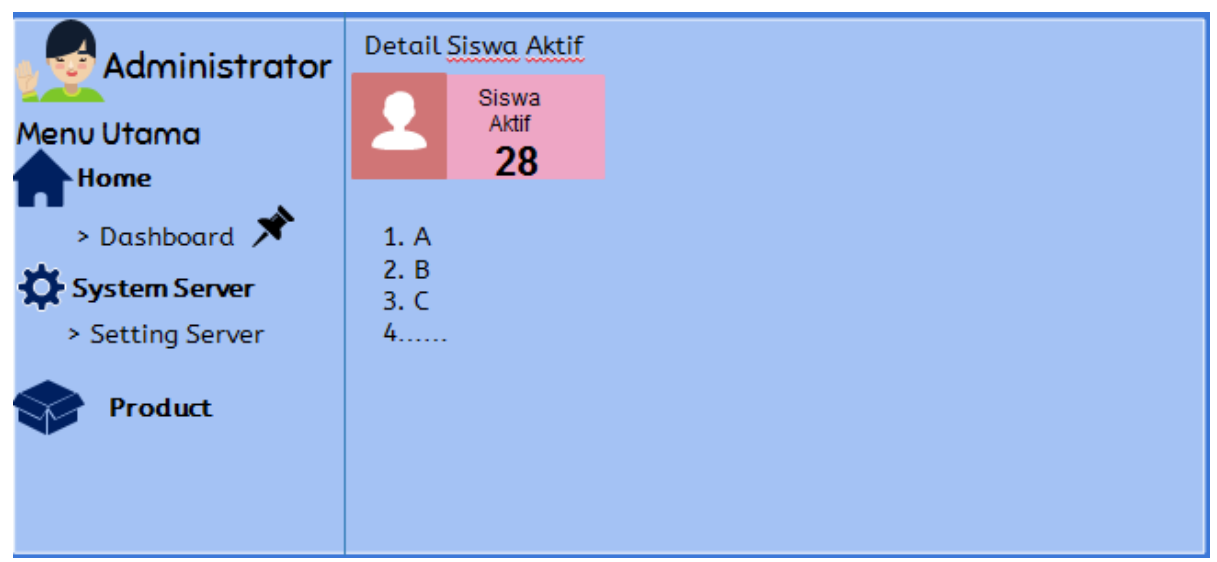

Gambar 22 Tampilan Fitur Dashboard Siswa Aktif

Fitur ini menampilkan identitas siswa yang sedang aktif mengakses aplikasi, akan ditampilkan detail identitas siswa yang sedang mengakses layanan aplikasi Literoom.

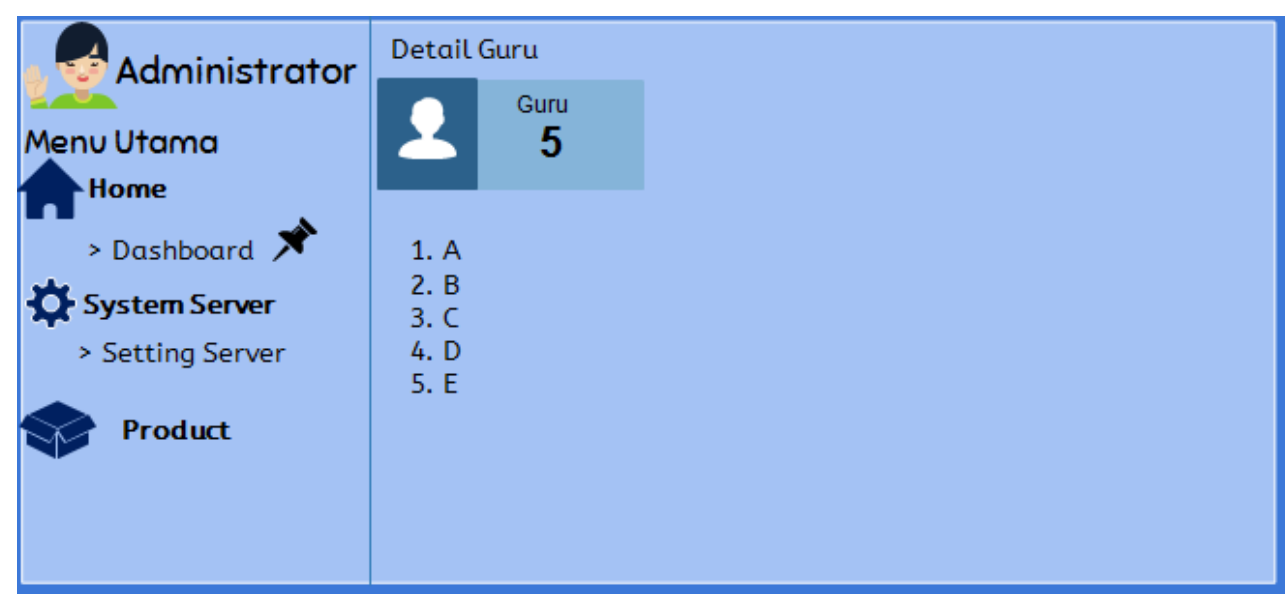

Gambar 23 Tampilan Fitur Dashboard Guru

Fitur ini menampilkan identitas guru yang sedang aktif mengakses aplikasi. Dalam hal ini guru tidak secara langsung mengakses layanan dari aplikasi Literoom, sebatas menerima hasil ringkasan siswa yang diterima dari email. 
Al-Ishlah: Jurnal Pendidikan - ISSN: 2087-949o (p); 2597-940X (e)

Vol. 12, No. 1 (2020)

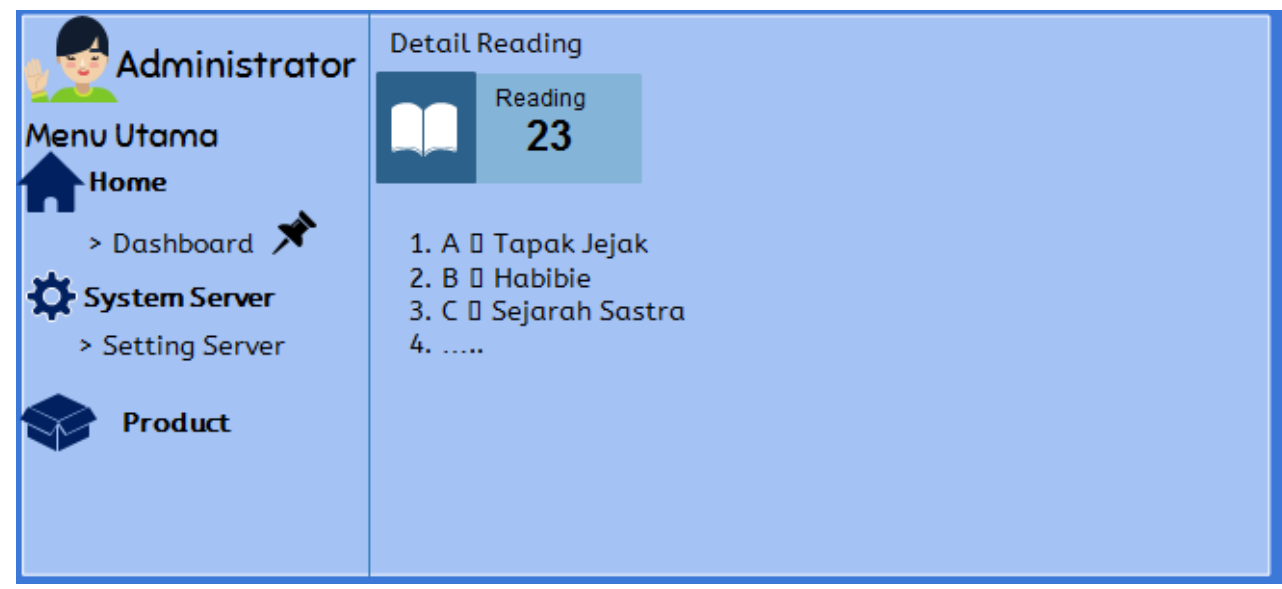

Gambar 24 Tampilan Fitur Dashboard Reading

Dalam fitur ini menampilkan detail siswa yang sedang mengakses layanan dari aplikasi Literoom, yakni pada bagian ruang baca. Admin dapat mengetahui buku bacaan apa yang sedang dibaca oleh siswa. Dalam hal ini buku yang diakses oleh user disediakan Kemendikbud dan Perpusnas yang diunggah oleh admin pada aplikasi Literoom. Berikut tampilan unggah buku.

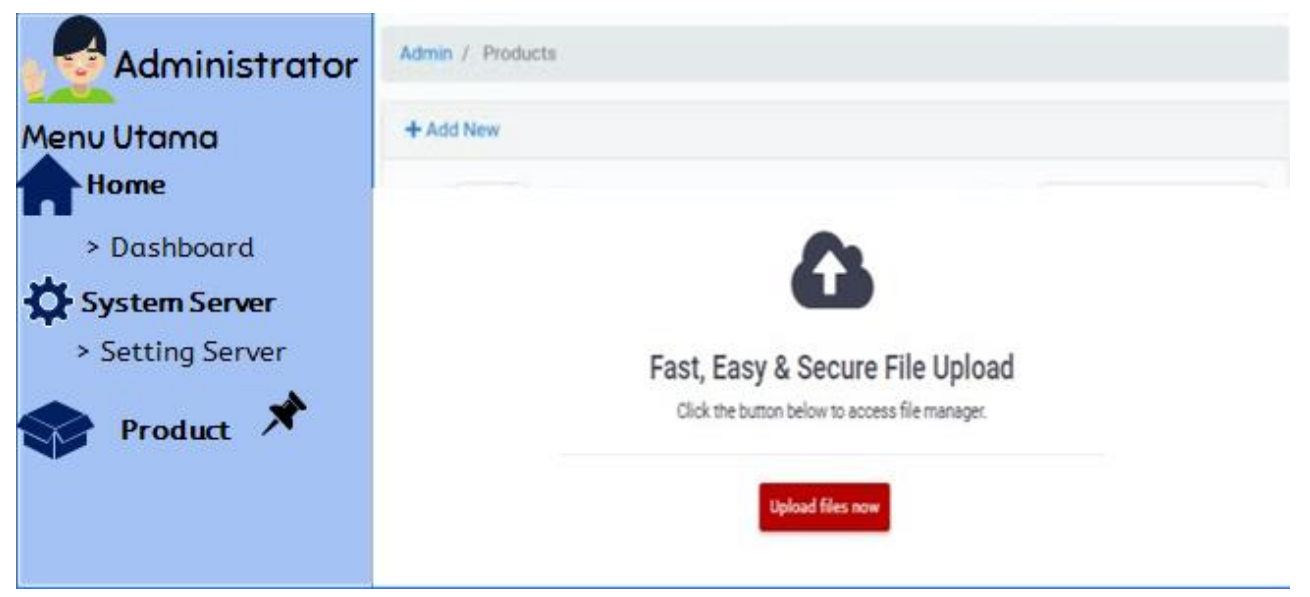

Gambar 25 Tampilan Fitur Product

Dari paparan mengenai perancangan aplikasi Literoom (ruang literasi) sebagai aplikasi penyedia ruang baca dalam rangka meningkatkan gerakan literasi sekolah. Aplikasi Literoom memiliki beberapa kelebihan dan kelemahan. Berikut uraian kelebihan dan kelemahan dari aplikasi Literoom.

Kelebihan:

1. Aplikasi ini dimanfaatkan untuk menyongsong era digital, khususnya dalam bidang pendidikan.

2. Menumbuhkan minat baca siswa.

3. Memudahkan siswa mengakses buku bacaan maupun modul. 
Al-Ishlah: Jurnal Pendidikan - ISSN: 2087-949o (p); 2597-940X (e)

Vol. 12, No. 1 (2020)

4. Mengurangi penggunaan kertas di Indonesia (paper less).

Kekurangan:

1. Bagi daerah 3T (terluar, terdepan, dan tertinggal) masih mengalami kesulitan dalam mengakses aplikasi Literoom.

2. Tampilan aplikasi Literoom masih sederhana.

\section{SIMPULAN}

Aplikasi Literoom merupakan aplikasi penyedia ruang baca yang diperuntukkan untuk anak sekolah mulai dari jenjang SD, SMP, dan SMA sederajat. Aplikasi ini tidak hanya menyediakan buku-buku online (e-book), namun juga dilengkapi dengan ruang untuk meresume hasil bacaan siswa yang nantinya bisa diserahkan atau dikirim kepada guru bahasa Indonesia untuk diketahui tingkat kemampuan siswa dalam hal literasinya. Dengan adanya rancangan berupa inovasi aplikasi Literoom sebagai aplikasi yang dapat memudahkan siswa dalam mengakses buku bacaan dan sebagai pendukung sumber belajar. Peneliti berharap rancangan aplikasi ini dapat ditingkatkan oleh penelitian selanjutnya. Selain itu, peran dari pemerintah, kemendikbud, perpustakaan, dan pihak akademisi sangat dibutuhkan untuk pengembangan layanan dari aplikasi Literoom ini.

\section{DAFTAR PUSTAKA}

Agustin, Ririn. (2013). "Knowledge Representation and Inference Engine Model of SAPS Gaming Conceptitle.” Procedia Technology 11 (1): 696-713.

Efendi, Yoyon. (2018). "Rancangan Aplikasi Game Edukasi Berbasis Mobile Menggunakan App Inventor." Rancangan Aplikasi Game Edukasi Berbasis Mobile Menggunakan App Inventor 2 (1): 41.

Huda, Miftakhul. (2018). "Strategi Berpikir Integratif dalam Pembelajaran Membaca Lintas Kurikulum di Sekolah Dasar”. Jurnal Kredo, 1(2): 26-35. https://doi.org/10.24176/kredo.v1i2.1995.

Isnanto, R Rizal., Aghus Sofwan, dan Arnold Fernando Sinaga. (2009). "Perancangan Aplikasi Agenda Ujian Tugas Akhir Berbasis Web". Jurnal Teknik Elektro, (1):165-172. 
Al-Ishlah: Jurnal Pendidikan - ISSN: 2087-949o (p); 2597-940X (e)

Vol. 12, No. 1 (2020)

Kasiyun, Suharmono. (2015). "Upaya Meningkatkan Minat Baca sebagai Sarana untuk Mencerdaskan Bangsa". JURNAL PENA INDONESIA (JPI) Jurnal Bahasa Indonesia, Sastra, dan Pengajarannya 1 (1): 1-17.

Kasiram, Moh. (2008). Metodologi Penelitian. Malang: UIN-Malang Pers.

Koltay, Tibor. (2011). "The Media and the Literacies: Media Literacy, Information Literacy, D igital Literacy." Media, Culture and Society 33(2): 211-21.

Leo Tiofan Justicia, Herman Tolle, Faizatul Amalia. (2017). "Rancang Bangun Aplikasi Messaging Berbasis Voice Interaction Bagi Penderita Tunanetra Pada Sistem Operasi Android." Jurnal Pengembangan Teknologi Informasi Dan Ilmu Komputer 1 (7): 620-27.

Listyorini, Tri. (2013). "Perancangan Mobile Learning Mata Kuliah Sistem Operasi Berbasis Android”. Jurnal Simetris, 3 (1): 25-30.

Manumpil, Beauty., Yudi Ismanto, dan Franly Onibala. (2015). "Hubungan Penggunaan Gadget dengan Tingkat Prestasi Siswa di SMA Negeri 9 Manado".ejoural Keperawatan (e-Kep) 3(2): 1-6.

Napitupulu, Darmawan Baginda. (2008). "Perancangan Sistem Informasi Pelatihan Koperasi Uji Mutu Berbasis Web". Jurnal Sistem Informasi MTIUI, Volume 4(1): 67-71.

Nafisah, Aliyatin. (2014). "Arti Penting Perpustakaan Bagi Upaya Peningkatan Minat Baca Masyarakat.” Jurnal Perpustakaan Libraria 2 (2): 70-81.

O'Brien, James. (2006). Pengantar Sistem Informasi, Perspektif Bisnis dan Manajerial. Jakarta: Salemba Empat.

Pressman, R.S. (2015). Rekayasa Perangkat Lunak: Pendekatan Praktisi Buku I. Yogyakarta: Andi.

Puncreobutr, Vichian. (2016). Lecturer-faculty,NewChallenge and Education St. n.d. "St. Theresa Journal of Humanities and Social Sciences" 2 (2): 1-4.

Sobri, Muhammad, and Leon Andretti (Bina Darma University) Abdillah. (2013). "Aplikasi Belajar Membaca Iqro' Berbasis Mobile 1)." Seminar Nasional Teknologi Informasi \& Multimedia (Semnasteknomedia), 1-6.

Sopandi, Debi. Dan Rinda Cahyana. (2016). "Pengembangan Fitur Peta Lokasi dari Aplikasi Penyedia Informasi Perumahan secaa Online". Jurnal Algoritma, 13 (1): 373-383. 
Al-Ishlah: Jurnal Pendidikan - ISSN: 2087-949o (p); 2597-940X (e)

Vol. 12, No. 1 (2020)

Surahman, Ence dan Herman Dwi Surjono. (2017)."Pengembangan Adaptive Mobile Learning pada Mata Pelajaran Biologi SMA sebagai Upaya Mendukung Proses Blended Learning".Jurnal Inovasi Teknologi Pendidikan, 4(1): 26-37.

Usman, Syaikhu. (2019). "Sekolah Masa Depan Di Era Digital - Belajar Dan Mengajar Di Mana Saja”. no. May 2018.

Wedhaswary, Dwi. (2012). “Jumlah Terbitan Buku Di Indonesia Rendah.” Kompas.com.

https://edukasi.kompas.com/read/2012/06/25/08121853/Jumlah.Terbitan.B uku.di.Indonesia.Rendah.

Zainul, Rahadian. (2016). "Studi Literasi Menggunakan Endnote dan Aplikasi Pembantu (Google Translator, Google Cendekia, Google Sites, Chemoffice 2018, E-Learning, dan Sipping Tool)". Seminar Akademik, Prodi Pendidikan IPA, FMIPA UNP, 1-11. 